\title{
自己評価的尺度における肯定的・否定的項目群因子の 年齢別の分析
}

\author{
——ローゼンバーグ自尊感情尺度と特性的自己効力感尺度——
}

福留広大*森永康子**

本研究は，自己評価的尺度を因子分析した際にしばしば得られる逆転項目（否定的項目）と順項目（肯定 的項目）の方法因子について, 自己評価的尺度一般にみられる現象かどうか, また, 年齢別の特徴がある かどうか，ローゼンバーグ自尊感情尺度と特性的自己効力感尺度を用いて検討した。調查デー夕は，15 歳から 69 歳の 2,830 名であった。研究 I では, ローゼンバーグ自尊感情尺度に自尊感情と方法因子を仮 定したモデルを検討するとともに，年齢が高くなるにつれて，方法因子の合成変数の相関が高くなる可 能性を検討した。その結果, 予想は支持された。研究 II では, ローゼンバーグ自尊感情尺度と特性的自 己効力感尺度を同時に分析した。その結果, それぞれの尺度に各構成概念とそれぞれに特有の方法因子 を仮定するモデルが支持された。一方で，両尺度の肯定的方法因子はナルシシズムと，両尺度の否定的 方法因子はストレス反応と, 尺度間でそれぞれ類似した関連を示したため, 自己評価的尺度一般に共通 の方法因子を仮定できる可能性も示唆された。この他, 因子負荷量について尺度間で異なる年齢的変化 を予想できる結果が得られた。

キーワード : 自尊感情尺度, 確認的因子分析, 特性的自己効力感尺度, ナルシシズム, 心理学的スト レス反応

\section{問題と目的}

本研究はローゼンバーグ自尊感情尺度 (Rosenberg's Self-Esteem Scale; RSES; Rosenberg, 1965）の構造を確認的因 子分析によって検討することを第一目的とし，その上 で心理尺度一般にみられる肯定的項目と否定的項目の それぞれの意味を理解する手がかりを得ることを目的 としている。

RSES は自尊感情を測定する尺度として妥当性と信 頼性が非常に高いことで知られ (Blascovich \& Tomaka, 1991），日本においても十分な使用実績がある（e.g., 小 塩・岡田・茂垣・並川・脇田, 2014)。通常, RSES は自尊感 情という単一の概念を測定するものであり，邦訳版に おいても山本・松井・山成 (1982) が単因子構造として 尺度構成している。しかし, 古くから RSES の因子構 造は単因子ではなく 2 因子である可能性が示唆されて きた。例えば, Carmines \& Zeller (1979) が高校生 350 名のデー夕に対して探索的因子分析を行い，2因子解 が得られたことを報告している。得られた因子は 5 項

\footnotetext{
* 広島大学 - 日本学術振興会特別研究員 DC (投稿時) d156702@outlook.jp

** 広島大学
}

目の逆転項目と 5 項目の逆転でない項目（以下，順項目) によってそれぞれ構成されており, 順項目群因子は PSE (Positive Self-Esteem), 逆転項目群因子は NSE (Negative Self-Esteem) と命名された。しかしながら, Carmines \& Zeller（1979）は 2 因子がその他の変数（社会経済的背 景, 心理学的傾性, 社会・政治的態度) との関係においてい かなる弁別性も持たなかったため,“アーティファクト によって 2 因子解が得られた”と結論している。した がって, 合成変数化する際 (項目平均で変数を作成する際) は 1 因子とみなした計算で問題ないと解釈できる。

ところが近年, RSESの因子構造が再検討されてい る。Marsh, Scalas, \& Nagengast (2010) は多特性多方法 行列 (Multi-Trait-Multi-Method matrix; MTMM matrix; Campbell \& Fiske, 1959) に基づき, 自尊感情尺度に自尊感情とい う特性因子と, それに加えて, 肯定的な項目による測 定方法因子 (以下, 肯定的方法因子) と否定的な項目によ る測定方法因子 (以下, 否定的方法因子) の 3 つの因子を 同時に検討するモデルを支持する結果を得ており，さ らに, 方法因子の心理学的意味の探索の必要性を指摘 している。本研究では, Marsh et al. (2010) のモデルと 指摘を基にして, 方法因子の心理学的意味について探 求する。 
Figure 1 に本研究で使用する仮説モデルを図示した。 図中モデル 1 は単因子構造であり, モデル 2 はPSE と NSE の 2 因子構造である。モデル 3 は自尊感情因子 (SE) と方法因子として肯定的方法因子 (PSE) と否定的 方法因子（NSE）を想定するモデルである。RSESでは 特性が一つに限られるが，このようなモデルはMTMM の文脈では CT-CM (Correlated Trait, Correlated Method) モ デルと呼ばれる。Marsh et al. (2010) と同様に，モデル 3 の可能性を示唆する研究には, 中高生を対象者とし た Urbán, Szigeti, Kökönyei, \& Demetrovics (2014), 高 齢者を対象とした Mullen, Gothe, \& McAuley (2013) や Lindwall et al. (2012) そして, Gana et al. (2013) があ る。また，モデル 2 は，服役経験のある人を対象にし た検討によって支持されている (Boduszek, Hyland, Dhingra, \& Mallett, 2013)。日本に押いては, 福留他 (2017) が中学生から高齢者までのサンプルを基に，1因子構 造と PSE と NSEによる 2 因子構造を比較して， 2 因子 構造の方が優れているとする結果を報告している1。ま た, 清水・吉田 (2008) は大学生を対象に, 本研究にお けるモデル 3 が認められる可能性を示唆しており, 日 本においても, PSE と NSE という因子が得られてい る。本研究では, これらの知見を基にして, ローゼン バーグ自尊感情尺度が日本の邦訳版においても同様に, モデル 3 のような構造となるかどうか検討することを 第一目的とする。

また，福留他（2017）では, PSE と NSE の相関につ いて, 基本的に相関係数は高いものの, 年齢が低いサ ンプルの 2 因子の相関係数は低く, 年齢が高いサンプ ルの 2 因子の相関係数は高い傾向にあることを報告し ているため, 本研究では年齢の差異についても同時に 検討する。仮に福留他（2017）の報告が支持されるので あれば, 自尊感情の因子構造は, 加齢に伴って 2 因子 から 1 因子に変化する傾向にあると考えることができ るのではないだろうか。また，上述した先行研究のい ずれにおいても，同一の調查で対象とする年齢層を幅 広く設定した研究はなく, 未検討課題として実施する

福留他（2017）では RSES の項目 8「もっと自分自身を尊敬で きるようになりたい」が除外されている。除外理由として，(a) 福留他（2017）で使用された全データセットに抏いて, 1 因子モ デルと 2 因子モデルに共通して, 項目 8 の因子負荷量が負の值, ないしは絶対值が小さい傾向にあること，（b） Schmitt \& Allik （2005）による53 か国別の因子分析 (1 因子解) の結果において も，日本を含む一部の国において負荷量が小さい，ないしは負の 值を示すこと，(c) 田中（2006）によって項目 8 は Rosenberg （1965）の自尊感情の定義に合わない可能性があると指摘されてい ること, 以上 3 点が挙げられている。本研究も同様の立場をとる。
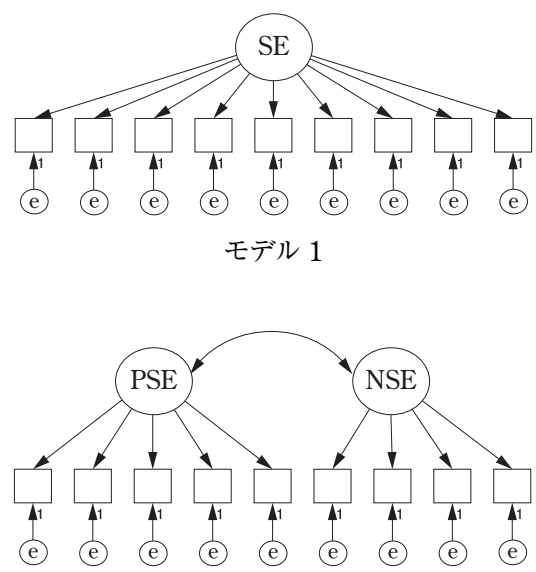

モデル 2

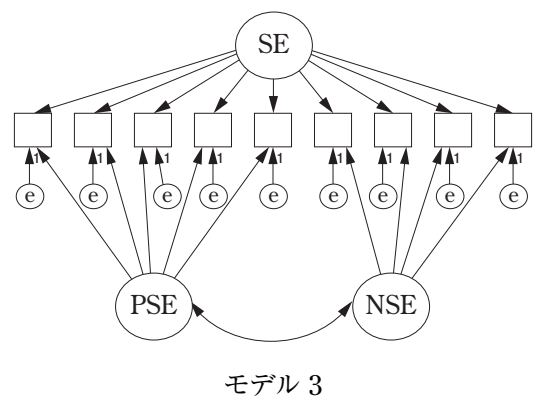

Figure 1 本研究が仮定するモデル

意義があるものと考えられる。

ここまでRSESに関する因子構造の議論を取り上げ たが, 本来, 肯定的方法因子と否定的方法因子はその 他の自己評価的尺度についても同様に仮定することが 可能と考えることもできる。例えば, 自尊感情に近い 概念と考えられ, 本研究が取り上げる特性的自己効力 感尺度（成田他, 1995）についても9 項目が肯定的項目, 14 項目が否定的項目 (逆転項目) の構成となっている。 尺度構成時は単因子構造が支持されており（成田他, 1995), 方法因子の存在可能性については検討されてい ない。もし, 特性的自己効力感尺度についても方法因 子を仮定したモデルの方が優れているという結果が得 られれば，方法因子は自己評価的尺度一般に存在する 可能性がある。また, 特性的自己効力感尺度に RSES の項目と共有の方法因子を仮定できない場合には, RSES の方法因子と特性的自己効力感尺度の方法因子 はそれぞれの尺度に特有なものであると解釈されうる。

このような, 方法因子の尺度一般への応用可能性に ついては，既に DiStefano \& Motl (2006) が検討してい 
る。検討された尺度は，身体に関する他者からの評価 不安尺度 (Social Physique Anxiety Scale; SPAS; Hart, Leary, \& Rejeski, 1989) であり，5項目が肯定的， 7 項目が否定的 である。分析の結果, SPASにおいても否定的方法因 子が存在することが見出されている（Figure 1 のモデル 3 から肯定的方法因子を除いたモデルを支持している)。また，

RSES と SPAS を同時に分析した場合においても両尺度 に否定的方法因子の存在を認め, 両尺度の否定的方法 因子間の相関を - . 37 と報告している。このことから, 否定的方法因子は否定的項目に対する反応スタイルを 測定している因子として尺度一般に仮定できる可能性 があると考えられる。しかしながら，DiStefano \& Motl (2006) は本研究のモデル 3 (Figure 1) の可能性について 検討していない。否定的項目に対する反応に，尺度全 体の概念との特異性があるとするのであれば，モデル 上は肯定的項目にも同時に方法因子を想定できる。実 際に Marsh et al. (2010) はモデル 3 を支持しているた め, 本研究においては検討対象とする。

以上の議論を踏まえて, 本研究の第二の目的として, 特性的自己効力感尺度についても方法因子を認めるこ とができるかどうか, 加えて, RSES と同時に分析を 行った際に，肯定的方法因子並びに否定的方法因子を 認めることができるかどうか検討を行うこととした。

本論文では, 以上の 2 つの目的のために調査を行い, その目的に沿った分析的観点より，研究 I と研究IIに 分けている。

\section{研 究 I}

本研究は日本における RSESの構造について, Figure 1 に示す確認的因子分析モデルによって検討すること を目的とする。また, 福留他 (2017) が述べた, PSEと NSEの相関は年齢が高いほど強い可能性についても検 討することを目的とする。

\section{方法}

\section{調査方法}

一般社団法人日本マーケティング・リサーチ協会に 所属し, プライバシーマークを取得しているインター ネット調査会社（楽天リサーチ株式会社）を通じてモニ ターに，個人が所有する端末上（PCやスマートフォンな ど）での回答を依頼した ${ }^{2}$ 。参加の同意は調査会社の形

個人情報保護方針については調查会社による次のページを参 考のこと。なお，著者は，本研究で個人の特定が可能になる情 報取得を行っていない。https://monitor.research.rakuten.co.jp/ explanation/privacy/(2018 年 1 月 23 日閲覧)
式で得た。また，回答者には，大学で行われている調 査研究であること, 回答に正誤はなくあまり深く考え る必要がないことを伝えた。

調査時期 2017 年 2 月

調査項目 ローゼンバーグ自尊感情尺度（山本他, 1982） 10 項目 5 件法（当てはまらない，やや当てはまらない， どちらともいえない, ややあてはまる, 当てはまる $)^{3}$ 。実際の 質問の構成としては, 本尺度を最初に尋ねた後, その ほかの項目が続くようになっていた。最終質問には楽 天リサーチ株式会社が提供する, 不誠実回答者を判別 するための質問が挿入され，その設問の教示文の指示 通りに回答しない回答者を不誠実回答者として，デー 夕から除外するよう設計された。形式の概要としては, “以下の項目から○○と $\times$ をを選択してください”とい う教示がなされるもので, その回答指示に従うことは 容易であった。

参加者及び分析対象者 日本全国の調査モニターを 対象に参加を依頼し, 最終的に調査会社から納められ たデータセット 2,830 名（男性 1,367 名, 女性 1,463 名）を そのまま分析対象とした。年歯範囲は 15 歳から 69 歳 であった $(M=37.657, S D=15.817)$ 。

分析ソフトウェア 以降, 本論文で行う分析は Microsoft Excel 2016 のアドインである BellCurve for Excell (エクセル統計) version 2.13（株式会社社会情報サー ビス, 2016）を用いて Microsoft Excel上で計算を行った。 また，共分散構造分析についてはAmos 24 (Arbuckle, 2015）を用い，デフォルト設定で分析を実行した。

分析方法 RSESにおける項目 8 は先行研究 (福留他, 2017）と同様に削除した 4 。逆転項目については逆転処 理がされたものを分析に用いた。本研究では Marsh et al. (2010) を基に分析モデルを設定しており, Figure 1 におけるモデル 3 を支持した場合は自尊感情尺度に多 次元性を認める結果と考える。一方で, モデル 3 につ いては, 正常な解が得られる確率が低いとされる (e.g., Marsh \& Bailey, 1991)。実際, Marsh et al. (2010) が検討 したモデルはモデル 3 だけではなかった。例えば，方 法因子という特殊因子を仮定するのではなく，その代 わりに同一方法因子の項目の残差間にすべての組み合わ せの共分散を仮定するモデル (Correlated Trait, Correlated Uniqueness; CT-CU; Kenny, 1976; Marsh \& Grayson, 1995) も検 討対象とされている。しかし，これについてはCT-CM が適切解でなかったときの使用に限った方が良いと主

\footnotetext{
尺度の具体的な項目, 実施方法については清水 (2001) pp. 29-31 を参照されたい。

注 1 を参照。
} 
張する論文 (Lance, Noble, \& Scullen, 2002) もあることか ら，本研究では積極的に用いる必要性のあるものでは ないとみなす。また, モデル 3 で適切解を得られない 場合は，2つある方法因子のいずれかを除いた CT-C (M-1) モデル (Correlated Trait, Correlated Method minus one model; Eid, 2000）の分析も考えられるが，このモデルは CT-CM モデルにおける識別性の問題を解決する分析 (Brown, 2015) であって，本来想定される因子を削除す ることになるので, 本研究では積極的に行う必要がな い分析とみなす。

本研究の分析は年齢別に因子構造, 特にPSE と NSE の相関が異なる可能性を含めて多母集団の同時分析を 行うこととした。複雑なモデルを分析するため，年齢 別に検討する上でも十分に人数を確保した上で分析を 実行する必要がある。そのため，年齢の四分位数を基 準に参加者を分け，4グループを設定した。各グルー プの内訳は, グループ $1: N=830,15-22$ 歳, $M_{\text {age }}=$ $20.443(S D=1.680)$; グループ $2: N=586,23$ - 34 歳, $M_{\text {age }}=28.654(S D=2.971)$; グループ $3: N=724,35-$ 51 歳, $M_{\text {age }}=43.282(S D=5.112)$; グループ $4: N=690$, 52 - 69 歳, $M_{\text {age }}=60.107(S D=5.005)$ であった。

また, PSEと NSEの相関に年齢による差異がある可 能性について, モデル 2 を用いて同時に検討した。こ の検証にモデル 3 ではなくモデル 2 を用いる理由とし ては, 実際にPSEと NSE という合成変数 (本研究では, 項目平均得点を想定している）を算出する意義を見出す目 的上では，より適切であると考えられるためである。

\section{結 果}

Figure 1 のモデルによる多母集団の同時分析を用い
た確認的因子分析の結果，全モデルにおいて，母集団 間で配置不変を認めるにとどまった。配置不変に加え 因子負荷量に等值制約を課すモデルについては, 配置 不変のモデルとの尤度比検定がすべて棄却されたため (モデル $1: \Delta \chi^{2}=183.311, \Delta d f=54, p<.001$; モデル $2: \Delta \chi^{2}=$ 74.596, $\Delta d f=27, p<.001$; モ デル $3: \Delta \chi^{2}=101.468, \Delta d f=27, p$ <.001), ここでは配置不変モデルの結果のみを記載す る (モデル $1: \chi^{2}=3243.087, d f=108, p<.001, \mathrm{CFI}=.742, \mathrm{GFI}=$ $.754, \mathrm{RMSEA}=.101, \mathrm{AIC}=3387.087$; モ デル $2: \chi^{2}=1101.563$, $d f=104, p<.001, \mathrm{CFI}=.918, \mathrm{GFI}=.915, \mathrm{RMSEA}=.058, \mathrm{AIC}=$ 1253.563; モ デル $3: \chi^{2}=283.785, d f=68, p<.001, \mathrm{CFI}=.982$, $\mathrm{GFI}=.979, \mathrm{RMSEA}=.034, \mathrm{AIC}=507.785)$ 。本研究における 最善はモデル 3 であった。次善はモデル 2 であり, モ デル 3 には劣るものの許容できると判断した。一方, モデル 1 については, モデル 2 からの悪化の幅が大き く，許容できる水準の適合度とは言えない。

次に, 最善モデルであったモデル 3 について標準化 解を Table 1 に示した。グループ 1 ではすべての NSE 項目の負荷量が SEの負荷量よりも絶対值で大きい值 をとり, PSE 項目についても一部が SEの負荷量より も絶対值で大きい。全体的な傾向として, 年䶡が高い 群になるにつれて, SEの負荷量が, 方法因子の負荷量 に相対して，大きくなる傾向を読み取ることができる。 また，グループ 3 とグループ 4 における項目 6,7 の PSEの負荷量が負になっており, 因子の負荷量に正の 值と負の值が混在している。さらに, PSE と NEの相 関 (共分散の標準化解) はグループ 2 で非有意となった。 最後に, 次善モデルである 2 因子モデルを用いて,

PSE と NSEの相関を求めた。相関係数はグループ 1 か ら順に, .467,.581,.658,.668であり，すべて $1 \%$ 水準

Table 1 研究 I RSES のモデル 3 における標準化解

\begin{tabular}{|c|c|c|c|c|c|c|c|c|c|c|c|c|}
\hline \multirow{2}{*}{ 項目番号 } & \multicolumn{3}{|c|}{ グループ 1（15-22 歳） } & \multicolumn{3}{|c|}{ グループ 2（23-34 歳） } & \multicolumn{3}{|c|}{ グループ 3（35-51 歳） } & \multicolumn{3}{|c|}{ グループ 4（52-69歳） } \\
\hline & $\mathrm{SE}$ & NSE & PSE & $\mathrm{SE}$ & NSE & PSE & $\mathrm{SE}$ & NSE & PSE & $\mathrm{SE}$ & NSE & PSE \\
\hline $3 R$ & $.088 n s$ & $.659^{* *}$ & & $.430 * *$ & $.516^{* *}$ & & $.477^{* *}$ & $480 * *$ & & $.845^{* *}$ & $.485^{* *}$ & \\
\hline $5 \mathrm{R}$ & $.211 * *$ & $.633 * *$ & & $.553 * *$ & $.371^{* *}$ & & $.526 * *$ & $341 * *$ & & $.788^{* *}$ & $231 * *$ & \\
\hline $9 \mathrm{R}$ & $.045 n s$ & $.836^{* *}$ & & $.484^{* *}$ & $.719^{* *}$ & & $.429 * *$ & $.745^{* *}$ & & $.775^{* *}$ & $.737 * *$ & \\
\hline $10 \mathrm{R}$ & $.250 * *$ & $.778 * *$ & & $.526 * *$ & $.648 * *$ & & $.585 * *$ & $602 * *$ & & $.646^{* *}$ & $.547^{* *}$ & \\
\hline 1 & $.801 * *$ & & $.410 * *$ & $.589^{* *}$ & & $.656^{* *}$ & $.836 * *$ & & $.209 *$ & $.658^{* *}$ & & $.282^{* *}$ \\
\hline 2 & $.672 * *$ & & $.461 * *$ & $.571^{* *}$ & & $.570^{* *}$ & $.824 * *$ & & $.197^{*}$ & $.500 * *$ & & $214 *$ \\
\hline 4 & $.601 * *$ & & $.380 * *$ & $.519^{* *}$ & & $.477^{* *}$ & $.737 * *$ & & $.169 *$ & $.564^{* *}$ & & $.079 n s$ \\
\hline 6 & $.293 *$ & & $.700 * *$ & $.703^{* *}$ & & $.203 n s$ & $.623 * *$ & & $-.303 * *$ & $.527 * *$ & & $-.226 * *$ \\
\hline 7 & $.183 n s$ & & $.787 * *$ & $.826^{* *}$ & & $.056 n s$ & $.721 * *$ & & $-.527 * *$ & $.624 * *$ & & $-.505 * *$ \\
\hline 共分散 & & & $.485^{* *}$ & & & $.138 n s$ & & & $-.201 *$ & & & $-.375 * *$ \\
\hline
\end{tabular}


で有意であった。

\section{考察}

本研究の目的は, 年齢群別による RSES の因子構造 の検討を行うことであった。その結果, RSES はモデ ル 3 の構造で最も良いあてはまりを示した。これは RSESにPSE と NSEの 2 つの方法因子を認める結果で あり，Marsh et al. (2010) や清水・吉田（2008）を支持 するものである。因子負荷量については, グループ 1 において SE という特性因子ょりも NSE という方法因 子の方が高い傾向にあった。これは, 自尊感情全体と してのまとまりょりも，NSEとしてのまとまりの方が 強いと解釈できる。実際, NSE の心理学的意味につい て, 福留他 (2017), 藤田・福留・古口・小林 (2017) で は，中学生デー夕においてストレス尺度の得点と NSE の関連は非常に密接なものであることが示されており, 方法因子を中心とした RSES の新たな解釈の可能性が 広がっていると思われる。つまり，RSESを 2 因子と みなした場合に，他の概念との関連がより適切に説明 できたり，自尊感情という概念の理解が進んだりする といった可能性が考えられる。

次に, 年齢が高い群になるにつれて, 全体的に方法 因子の負荷量に比して SE の負荷量が高くなる傾向に あることから，これら 3 因子の関係に年齢的変化が推 測できるだろう。また，グループ 3 とグループ 4 にお ける PSE の負荷量の值に正の值と負の值が混在してい た。解釈としては, 年齢によって PSE 項目としての意 味が異なっていることが考えられる。正の值を示した 項目は項目番号 1,2,4 (項目 4 についてはグループ4でn.s.) であり，項目内容は順に，「少なくとも人並みには，価 值のある人間である」，「色々な良い素質をもってい る」「物事を人並みには，うまくやれる」である。一 方，負の值を示した項目は項目番号 6,7 であり，項目 内容は順に「自分に対して肯定的である」，「だいたい において，自分に満足している」である。正負の違い が生じた理由は, 後者に比べ, 前者 (項目 1,2,4) は自 己評価ではあるものの外的な基準を参照して回答され やすい項目であるためではないかと推測できる。つま り, 年齢が高くなるほど, 外的な基準の存在が何らか の影響を与えることが示唆され，可能性の一つとして 肯定的方法因子の分化も考えられる。しかし，モデル 全体としては，方法因子の負荷量に比して SE の負荷 量が高くなる傾向があるという点が年齢による差異に ついての重要な結果であろう。

また，モデル 3 グループ 2 の PSE と NSE の相関が
非有意になったこともその年齢的変化によるものだと 推察される。モデル 2 における PSE と NSE の相関係 数は年齢が高いグループになるほど高くなる傾向にあ ることが明らかになった。つまり，PSEと NSEという 合成得点を算出した場合，年齢が高いほどその両者の 相関が強くなることが明らかになった。

以上のことから, 年齢が高くなるにつれて方法因子 の合成得点の相関係数は高くなり，その結果として概 念全体として統合される，すなわち SEとして収束す る統合過程の存在が示唆されるのではないだろうか。 本研究上で述べる加齢による統合とは, 方法因子とし てのまとまりょりも特性因子としてのまとまりが強固 になることである。若年層では方法因子の負荷量が特 性因子の負荷量に比して高い傾向にあるが，中・高年 層では特性因子の負荷量が方法因子の負荷量に比して 高い傾向にあることから，加齢による統合過程が推察 される。年齢が低いうちは, 肯定と否定で分化した自 己評価の様相があり, それが徐々に統合されていく過 程が自己の発達に含まれているのかもしれない。

\section{研 究 II}

研究 I では, RSES に多次元性が認められる結果を 得たが，これは自己評価的尺度一般について応用する ことができるのではないだろうか。研究II の第一目的 は, DiStefano \& Motl (2006) がSPAS を用いて検討し たように, 特性的自己効力感尺度に対して Figure 1 の モデルを応用できるかどうか検討することにある。

しかし, 仮にモデル 3 を特性的自己効力感尺度に応 用できたとしても，それだけで，方法因子が自己評価 的尺度一般にみられる現象であると判断するには十分 でない。そこでまず, DiStefano \& Motl (2006) を参考 に RSES と特性的自己効力感尺度を同時に分析するモ デルを新たに追加する (Figure 2)。また, Marsh et al. （2010）が, 得られた方法因子の心理学的意味について 検討することが重要である, と主張しているように, 本研究ではその点についても検討する必要がある。仮 に，RSESに㧍ける方法因子の考え方が，その他の自 己評価尺度一般に応用できるのであれば，RSES と特 性的自己効力感尺度の肯定的（否定的）方法因子は, そ れぞれ第 3 の基準変数と類似した関連にあるだろう。 この目的のため, 第 3 の基準変数との関連を基に方法 因子に関する議論を行う。

本研究が扱う基準変数は, 心理尺度により測定され るストレス反応とナルシシズムである。ストレス反応 との関連については, 福留他 (2017) や藤田他 (2017) 


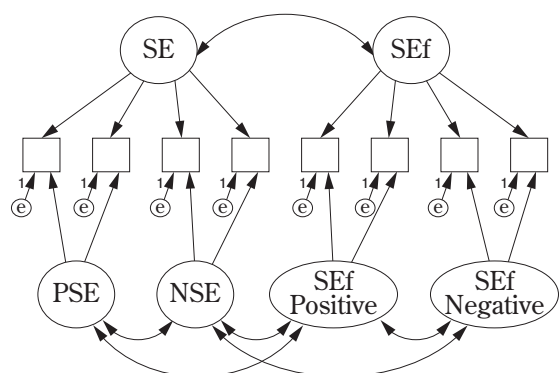

モデル 4

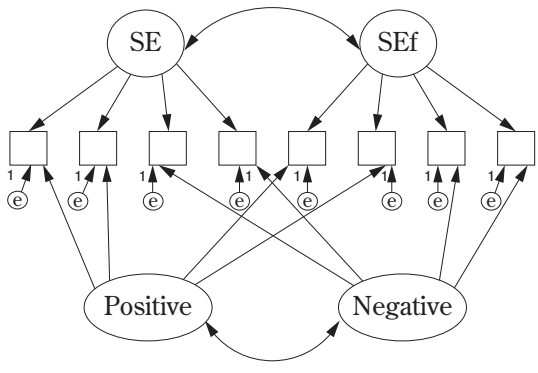

モデル 5

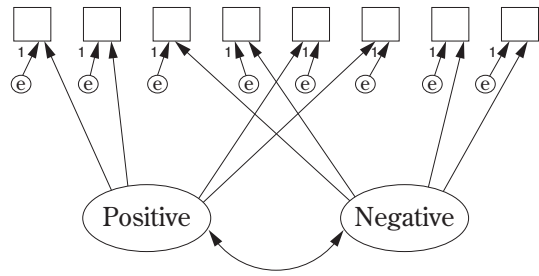

モデル 6

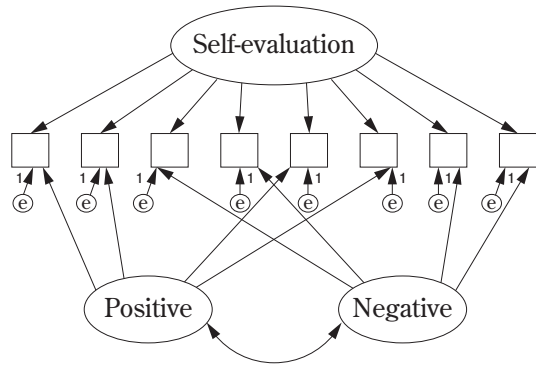

モデル 7

Figure 2 研究II において追加されるモデル図

注） 観測変数については図示が可能な範囲以外は省略している。観測変数はすべてのモデルで RSES と特性 的自己効力感尺度の項目数と同数, 存在している。SEf とは自己効力感 (Self-efficacy) のことである。モ デル 6, 7 は 2 尺度を同時に分析する点で, Figure 1 のモデル 2, 3 とは異なる。

にあるように，NSE との関連が PSE との関連よりも強 くなることが予想される。ナルシシズムについては小 塩（1997）が報告しているようにPSE との関連が NSE との関連よりも強いものと予想される ${ }^{5}$ 。つまり，これ らの変数と方法因子の関連性について, RSES と特性 的自己効力感尺度からそれぞれ類似する結果を得られ れば, RSESにみられるPSE と NSE は，自己評価的尺 度一般に存在する可能性があると判断できる。

自己効力感とは,「個人がある状況において必要な行 動を効果的に遂行できる可能性の認知」を指し（成田他， 1995), 特性的自己効力感は, 個人の人格的側面として 自己効力感を捉えるものである。日本における尺度作 成研究では RSES とは. 56 の正の相関が得られている

5 小塩（1997）によると, 大学生・短大生・専門学生を対象に, 「ローゼンバーグによる自尊感情尺度 10 項目（安藤, 1987）と Cheek \& Buss の自尊感情尺度 6 項目（Cheek \& Buss, 1981; Buss, 1986 大渆訳 1991）を組み合わせたものを 2 件法（当ては まる, 当てはまらない) で尋ねた」結果, 本研究が述べている PSE と NSE の存在を見出している。加えて, PSE と自己愛の 正の相関が, NSE と自己愛の正の相関よりも強いことを報告し ている。
(成田他, 1995)。さらに, 自尊感情と特性的自己効力感に は同一の高次概念 ${ }^{6}$ を認めることができるとする研究も 存在する (Judge, Erez, Bono, \& Thoresen, 2002)。このよう に，概念的に近いと考えられる特性的自己効力感を用 いることは, 自己評価的尺度に一般に肯定的方法因子 と否定的方法因子がみられるかどうか検討する最初の 段階として，妥当であると考えられる。

\section{方法}

方法については以下の点を除いて研究 I と同じであ り，かつ，同一データセットに対する分析である。

\section{調査項目}

研究 I の自尊感情尺度の後に続いて特性的自己効力 感尺度 23 項目 5 件法に回答を求めた。その後, 基準変 数の測定を行った。まず，ストレス反応はPublic Health Research Foundation ストレスチェックリス ト・ショートフォーム（今津他, 2006) 24 項目 3 件法（な

6 Judge et al. (2002) では, 自尊感情と特性的自己効力感の他 に, ローカス・オブ・コントロールと神経症傾向を含めた計 4 因子に対する高次因子分析が行われている。 
い，時々ある，よくある）によって測定した。ストレス反 応尺度については参加者ごとに項目順がランダムにな るように設計した。次に，ナルシシズムは日本語版 Dark Triad Dirty Dozen（DTDD-J; 田村・小塩・田中・増 井・Jonason, 2015）の下位尺度 4 項目 5 件法によって測定 した。以上の 2 つの基準変数中には逆転項目は含まれ ていない。

\section{分析方法}

逆転項目のデータについては最初に逆転処理を行っ た。まず，特性的自己効力感尺度について, Figure 1 に想定されたモデルを使用した。項目数が異なってい るがモデル図は省略する。 RSES と特性的自己効力感 尺度の 2 つの尺度を同時に分析するモデルを Figure 2 に示した。モデル 4 は DiStefano \& Motl (2006) による 検討に基づいて，肯定・否定的方法因子を同時に検討 するモデルに改変した。RSES と特性的自己効力感尺 度を同時に分析し，それぞれ特有の方法因子を仮定す るモデルである。モデル 5 は, RSES と特性的自己効 力感尺度が肯定的方法因子と否定的方法因子をそれぞ れ共有していると仮定した。モデル 6 は両尺度を使用 しているが，方法因子のみが仮定されるモデルである。 モデル 7 は RSES と特性的自己効力感尺度を同一の概 念とみなし，自己評価（Self-evaluation）とした因子を仮 定し，かつ方法因子が同時に仮定されるモデルである。 想定する母集団は研究 I と同じであった。以上のよう に新たに 4 モデルを仮定し，比較することによって RSES と特性的自己効力感尺度に共通の特性因子ない しは方法因子を仮定できる可能性について探索した。

\section{結果}

最初に特性的自己効力感尺度のみに対して Figure 1 のモデルを応用した。その結果, すべて配置不変モデ ルと配置不変に加え因子負荷量に制約を課すモデル間 の尤度比検定が有意であったため（モデル $1: \Delta \chi^{2}=$ 244.553, $\Delta d f=66, p<.001$; モデル $2: \Delta \chi^{2}=105.308, \Delta d f=63$, $p<.001 ;$ モデル $\left.3: \Delta \chi^{2}=318.402, \Delta d f=138, p<.001\right)$, すべて のモデルで配置不変モデルが妥当であると判断した。 それぞれの適合度は，モデル $1: \chi^{2}=9921.186, d f=920$, $p<.001, \mathrm{CFI}=.653, \mathrm{GFI}=.703, \mathrm{RMSEA}=.059, \mathrm{AIC}=$ 10289.186; モデル $2: \chi^{2}=8074.707, d f=916, p<.001$, $\mathrm{CFI}=.724, \mathrm{GFI}=.745, \mathrm{RMSEA}=.053, \mathrm{AIC}=8450.707$; モデル $3: \chi^{2}=4211.630, d f=824, p<.001, \mathrm{CFI}=.870$, $\mathrm{GFI}=.876, \mathrm{RMSEA}=.038, \mathrm{AIC}=4771.630$, であっ た。いずれのモデルも十分な適合度を示しているとは 言えないが, モデル 3 が最善であり, 許容範囲内とし
た。また，モデル 2 における方法因子間の相関はグ ループ 1 から順に, .347, .569, .703, .774であった。最 善モデルであったモデル 3 については標準化解をTable 2 に示した。年齢が高いグループほど, 方法因子の相 関係数は高いことがわかる。

次に, Figure 2 を用いた多母集団の同時分析の配置 不変 (制約なし) の際の適合度を示す（モデル $4: \chi^{2}=$ 7528.853, $d f=1708, p<.001, \mathrm{CFI}=.861, \mathrm{GFI}=.847, \mathrm{RMSEA}=$ $.035, \mathrm{AIC}=8336.853 ;$ モデル $5: \chi^{2}=8064.162, d f=1720, p<.001$, $\mathrm{CFI}=.848, \mathrm{GFI}=.832, \mathrm{RMSEA}=.036, \mathrm{AIC}=8848.162 ;$ モデル $6:$ $\chi^{2}=14446.057, d f=1852, p<.001, \mathrm{CFI}=.699, \mathrm{GFI}=.692$, $\mathrm{RMSEA}=.049, \mathrm{AIC}=14966.057 ;$ モデル $7: \chi^{2}=10386.089, d f=$ $1724, p<.001, \mathrm{CFI}=.793, \mathrm{GFI}=.770, \mathrm{RMSEA}=.042, \mathrm{AIC}=$ 11162.089)。いずれのモデルも基準を満たしていない が, $d f$ が非常に大きいことを踏まえればモデル 4 とモ デル 5 は許容できるものと思われる。最善モデルはモ デル 4 であり自尊感情と自己効力感を別の因子とみな し, さらに方法因子もそれぞれに固有なものを仮定し ている。Table 3 にはモデル 4 における因子間の相関関 係についてまとめた。グループ 1 では SE と特性的自 己効力感の間の相関が低い一方, 肯定的方法因子と否 定的方法因子のそれぞれで尺度（特性）間に高い相関関 係が見られた。また，年齢の高いグループほど否定的 方法因子の尺度 (特性) 間の相関関係が弱くなる傾向に あった。両尺度 (特性) の相関係数は年齢が高いグルー プほど高い傾向にあった。特性的自己効力感尺度内の $2 つ の$ 方法因子の相関係数は年齢が高いグループほど 高い傾向にあった。

最後に, 基準変数と各因子の相関関係について, Table 4 に示した。なお，ストレス尺度に対して全サン プルにおける探索的因子分析を行った際, 固有值が 9.477, 1.731，1.419, 0.941 という減衰をしたため, 一次元性を仮定しても良いと判断した。ストレスと自 尊感情では, すべてのグループにおいて, 否定的方法 因子 (NSE) との関連が強く, その程度は肯定的方法因 子 (PSE) や SE といった全体の得点との関連よりも強 い傾向にあった 7 。また, 特性的自己効力感においても

各基準変数と方法因子の尺度得点の相関と各基準変数と特性 因子の尺度得点の相関の差についての検定結果を Table 4 に示 した。検定は，ストレスと SE (SEf) の相関係数とストレスと NSE (SEf Nega) の相関係数の差, 及び, ナルシシズムと SE (SEf) の相関係数とナルシシズムと PSE (SEf Posi) の相関係数 の差,について行った（各特性因子と各グループの計 16 対）。 全ての相関係数の対において有意な差があるとは認められない ものの, 係数の大小関係は一貫しており多くの場合で有意な結 果となっている。 
Table 2 研究IIに扔ける特性的自己効力感尺度の確認的因子分析の結果

\begin{tabular}{|c|c|c|c|c|c|c|c|c|c|c|c|c|}
\hline \multirow[b]{2}{*}{ 項目番号 } & \multicolumn{3}{|c|}{ グループ 1（15-22 歳） } & \multicolumn{3}{|c|}{ グループ 2（23-34 歳） } & \multicolumn{3}{|c|}{ グループ 3（35-51 歳） } & \multicolumn{3}{|c|}{ グループ 4（52-69 歳） } \\
\hline & SEf & $\begin{array}{c}\text { SEf } \\
\text { Nega }\end{array}$ & $\begin{array}{l}\text { SEf } \\
\text { Posi }\end{array}$ & SEf & $\begin{array}{c}\text { SEf } \\
\text { Nega }\end{array}$ & $\begin{array}{l}\text { SEf } \\
\text { Posi }\end{array}$ & SEf & $\begin{array}{l}\text { SEf } \\
\text { Nega }\end{array}$ & $\begin{array}{l}\text { SEf } \\
\text { Posi }\end{array}$ & SEf & $\begin{array}{l}\text { SEf } \\
\text { Nega }\end{array}$ & $\begin{array}{l}\text { SEf } \\
\text { Posi }\end{array}$ \\
\hline $2 \mathrm{R}$ & $.068 n s$ & $.509^{* *}$ & & $.127 *$ & $.500 * *$ & & $.086 n s$ & $.518 * *$ & & $.149 * *$ & $.448 * *$ & \\
\hline $4 \mathrm{R}$ & $.623 * *$ & $.447^{* *}$ & & $.624 * *$ & .469 ** & & $.566 * *$ & $.505 * *$ & & $.569 * *$ & $.505 * *$ & \\
\hline $5 \mathrm{R}$ & $.082 n s$ & $.698^{* *}$ & & $.094 n s$ & $.667 * *$ & & $-.039 n s$ & $.682 * *$ & & $-.061 n s$ & $.733 * *$ & \\
\hline $6 \mathrm{R}$ & $-.087 n s$ & $.791 * *$ & & $-.125 *$ & $.752 * *$ & & $-.153 *$ & $.813 * *$ & & $-.163 *$ & $.774 * *$ & \\
\hline $8 \mathrm{R}$ & $.231 * *$ & $.613^{* *}$ & & $.253 * *$ & $.563^{* *}$ & & $.250 * *$ & $.554 * *$ & & $.215^{* *}$ & $.563 * *$ & \\
\hline $9 \mathrm{R}$ & $.279 * *$ & .593 ** & & $.276 * *$ & $.528^{* *}$ & & $.204^{* *}$ & $.562 * *$ & & $.173^{* *}$ & $.495 * *$ & \\
\hline $10 \mathrm{R}$ & $.336 * *$ & $.595^{* *}$ & & $.356 * *$ & $.522 * *$ & & $.342 * *$ & $.497 * *$ & & $.388 * *$ & $.475^{* *}$ & \\
\hline $13 \mathrm{R}$ & $-.040 n s$ & $.708 * *$ & & $-.047 n s$ & $.704^{* *}$ & & $.001 n s$ & $.741 * *$ & & $-.069 n s$ & $.702 * *$ & \\
\hline $15 \mathrm{R}$ & $.112^{* *}$ & $.624^{* *}$ & & $.102 *$ & .639 ** & & $.082 n s$ & $.634 * *$ & & $-.072 n s$ & $.734 * *$ & \\
\hline $16 \mathrm{R}$ & $-.057 n s$ & $.680^{* *}$ & & $-.135 *$ & $.704^{* *}$ & & $-.042 n s$ & $.593^{* *}$ & & $-.023 n s$ & $.677^{* *}$ & \\
\hline $18 \mathrm{R}$ & $.412^{* *}$ & $.576^{* *}$ & & $.464 * *$ & $.526^{* *}$ & & $.480 * *$ & $.561 * *$ & & $.350 * *$ & $.571 * *$ & \\
\hline $19 \mathrm{R}$ & $.364 * *$ & $.562^{* *}$ & & $.429 * *$ & .491 ** & & $.392 * *$ & $.558 * *$ & & $.248^{* *}$ & $.572 * *$ & \\
\hline $22 \mathrm{R}$ & $-.119 * *$ & $.813^{* *}$ & & $-.150 * *$ & $.800 * *$ & & $-.108 n s$ & $.777 * *$ & & $-.101 n s$ & .736 ** & \\
\hline $23 \mathrm{R}$ & $.081 n s$ & $.632^{* *}$ & & $.006 n s$ & $.672^{* *}$ & & $.048 n s$ & $.583^{* *}$ & & $-.068 n s$ & .590 ** & \\
\hline 1 & $-.056 n s$ & & $.564^{* *}$ & $.031 n s$ & & $.495 * *$ & $.021 n s$ & & $.572 * *$ & $-.184 * *$ & & $.672^{* *}$ \\
\hline 3 & $-.228 * *$ & & $.663^{* *}$ & $-.370 * *$ & & $.649 * *$ & $-.243 * *$ & & $.639 * *$ & $-.317 * *$ & & $.637^{* *}$ \\
\hline 7 & $.164 * *$ & & $.493^{* *}$ & $.263 * *$ & & $.491 * *$ & $.168^{* *}$ & & $.421 * *$ & $.162^{* *}$ & & $.505^{* *}$ \\
\hline 11 & $-.274 * *$ & & $.562^{* *}$ & $-.371 * *$ & & $.606 * *$ & $-.321 * *$ & & $.571 * *$ & $-.309 * *$ & & $.500 * *$ \\
\hline 12 & $-.036 n s$ & & $.553 * *$ & $.051 n s$ & & $.568 * *$ & $.021 n s$ & & $.523 * *$ & $.066 n s$ & & $.558 * *$ \\
\hline 14 & $.315^{* *}$ & & $.508 * *$ & $.371 * *$ & & $.480 * *$ & $.360^{* *}$ & & $.372 * *$ & $.304^{* *}$ & & $.413^{* *}$ \\
\hline 17 & $-.164^{* *}$ & & $.663^{* *}$ & $-.238 * *$ & & $.612^{* *}$ & $-.147 * *$ & & $.601 * *$ & $-.153 *$ & & $.529^{* *}$ \\
\hline 20 & $-.228 * *$ & & $.213^{* *}$ & $-.243 * *$ & & $.013 n s$ & $-.233 * *$ & & $.218 * *$ & $-.339 * *$ & & $.278^{* *}$ \\
\hline 21 & $.632 * *$ & & $.542^{* *}$ & $.661 * *$ & & $.507 * *$ & $.674 * *$ & & $.446 * *$ & $.636^{* *}$ & & $.510 * *$ \\
\hline 共分散 & & & $.358 * *$ & & & $.561 * *$ & & & $.698 * *$ & & & $.770 * *$ \\
\hline
\end{tabular}

注） R は Reversedの略であり，逆転項目の逆転処理済みを意味する。すべて多母集団の同時分析における制約なし（配置不変）の結 果。SEf は自己効力感（Self-efficacy）の略として使用しており, Nega は Negative, Posi は Positiveの略である。グループ 3 と 4 で は SEf Nega の負荷量全てと共分散がソフトウェア上，負の值で出力されたため，表ではわかりやすさのために-1を掛けた值を報 告している。

${ }^{*} p<.05 \quad * * p<.01$

Table 3 研究II モデル 4 における因子間相関

\begin{tabular}{llclcc}
\hline \multicolumn{2}{c}{ 変数対 } & グループ 1 & グループ 2 & グループ 3 & グループ 4 \\
\hline SE & SEf & $.288^{* *}$ & $.588^{* *}$ & $.458^{* *}$ & $.713^{* *}$ \\
PSE & NSE & $.239^{* *}$ & $.246^{* *}$ & $.341^{* *}$ & $-.161^{*}$ \\
SEf Posi & SEf Nega & $-.087^{* *}$ & $.288^{* *}$ & $-.509^{* *}$ & $-.599^{* *}$ \\
SEf Posi & PSE & $.660^{* *}$ & $.579^{* *}$ & $.308^{* *}$ & $.530 * *$ \\
SEf Nega & NSE & $-.703^{* *}$ & $.604^{* *}$ & $-.477^{* *}$ & $-.122^{*}$ \\
\hline
\end{tabular}

注） SEfは自己効力感 (Self-efficacy) の略として使用しており, Negaは Negative, Posi は Positive の略である。正負の解釈は実際の項目平均得 点間の相関とは異なる（グループ 1, 3, 4 の SEf Nega において因子負荷 量が負の值となった。ただし, グループ 4 では 3 項目で正の值が含まれ, うち 2 項目は非有意であった)。 $* p<.05 \quad * * p<.01$

同様の傾向にあった。一方，ナルシシズムと肯定的方 法因子との関連についても同様の傾向がみられ，ナル シシズムと全体の得点との関連よりも肯定的方法因子 との関連の方が強い傾向にあった。ナルシシズムにつ いてはグループ 1 が他のグループとは異なる傾向を示
しており, PSE との相関は.414, SEf Posi と.338であ る一方, NSEやSEf Nega とは有意な相関関係になかっ た。なお，ストレスとナルシシズムの相関係数は全て のグループにおいて, 有意な相関係数でないかまたは 有意でも小さい值 $(r \mathrm{~s}<.10)$ であった。 
Table 4 研究IIにおけるグループ別の基準変数との積率相関

\begin{tabular}{|c|c|c|c|c|c|c|c|}
\hline & $\mathrm{SE}$ & PSE & NSE & SEf & SEf Posi & SEf Nega & ストレス \\
\hline \multicolumn{8}{|l|}{ グループ 1（15-22 歳） } \\
\hline ストレス $(\alpha=.935)$ & $-.397 * *$ & $-.215 * *$ & $-.473 * * \mathrm{a}$ & $-.447 * *$ & $-.177^{* *}$ & $-.467 * * \mathrm{c}$ & \\
\hline ナルシシズム $(\alpha=.850)$ & $.290 * *$ & $.414 * *$ a & $.046 n s$ & $.111^{* *}$ & $.338 * *$ a & $-.047 n s$ & $.073 *$ \\
\hline \multicolumn{8}{|l|}{ グループ 2（23-34 歳） } \\
\hline ストレス $(\alpha=.931)$ & $-.398 * *$ & $-.261 * *$ & $-.448 * * \mathrm{~b}$ & $-.420 * *$ & $-.190 * *$ & $-.455 * *$ a & \\
\hline ナルシシズム $(\alpha=.870)$ & $.222 * *$ & $.277 * * \mathrm{a}$ & $.101 *$ & $.152^{* *}$ & $.193 * * \mathrm{c}$ & $.099 *$ & $.063 n s$ \\
\hline \multicolumn{8}{|l|}{ グループ 3（35-51 歳） } \\
\hline ストレス $(\alpha=.930)$ & $-.454 * *$ & $-.343 * *$ & $-.474 * * \mathrm{c}$ & $-.443 * *$ & $-.240 * *$ & $-.480 * *$ a & \\
\hline ナルシシズム $(\alpha=.888)$ & $.106 * *$ & $.153 * *$ a & $.031 n s$ & $.038 n s$ & $.103 * * \mathrm{c}$ & $-.002 n s$ & $.074 *$ \\
\hline \multicolumn{8}{|l|}{ グループ 4（52-69 歳） } \\
\hline ストレス $(\alpha=.921)$ & $-.393 * *$ & $-.286 * *$ & $-.432 * * \mathrm{~b}$ & $-.456 * *$ & $-.312 * *$ & $-.471 * * \mathrm{c}$ & \\
\hline ナルシシズム $(\alpha=.898)$ & $.178 * *$ & $.239 * * \mathrm{a}$ & $.079 *$ & $.121 * *$ & $.167 * * \mathrm{~b}$ & $.079 *$ & $.050 n s$ \\
\hline
\end{tabular}

注） SEf は自己効力感 (Self-efficacy) の略として使用しており，Nega は Negative，Posi は Positive の略である。 ストレスは尺度の合計得点，その他は全て尺度の項目平均得点を使用している。基準変数を除く各変数の $\alpha$ の最低值は, SE: $\alpha=.852$; PSE: $\alpha=.853$; NSE: $\alpha=.827$; SEf: $\alpha=.880$; SEf Posi: $\alpha=.718$; SEf Nega: $\alpha=.895$, であった。係数右上のアルファベットは相関係数の差の検定結果であり（a: $p<.01, \mathrm{~b}: p<.05, \mathrm{c}: n s)$, ストレ スについては, 1列目（SE）と 3 列目（NSE）の係数比較, 及び, 4列目（SEf）と6列目（SEf Nega）の係 数比較である。ナルシシズムについては，1列目（SE）と2列目（PSE）４列目（SEf）と5列目（SEf Posi） の倸数比較である。

$p<.05^{*} \quad p<.01^{* *}$

\section{考察}

研究 II では特性的自己効力感尺度を分析に加え, RSES と同時に分析することで検証するモデルを拡張 した。また, 方法因子の心理学的意味を検討するため, 第 3 の基準変数を分析に加えた。

まず，因子構造に関する考察を行う。研究 IIには, 特性的自己効力感尺度の因子構造の検討に始まり, 自己評価的尺度一般に関する検討に拡張する目的が あった。まず，特性的自己効力感尺度について単体で Figure 1のモデルを用いて分析を行ったところ，モデ ル 3 が最善モデルとなった。これについては研究 I の RSES の結果に沿うものである。次に，モデル 3 にお ける各グループでの方法因子同士の相関関係が，年齢 が高いグループほど強くなる傾向にあった。これは研 究 I での RSES 単体における結果と異なり, この原因 は特性因子の負荷量にあると考えられる。研究 I にお ける RSES 単体の分析では，年齢が高くなるほど特性 因子 (SE) の因子負荷量が大きくなり, 方法因子の負 荷量が小さくなる傾向にあったが, Table 2 の特性的自 己効力感尺度の結果からはその傾向を読み取ることが できない。すなわち, 特性的自己効力感尺度では年齢 が高いほど単純にモデル 3 における方法因子の相関が 高くなる傾向にあり, RSES とは異なる年齢的変化が

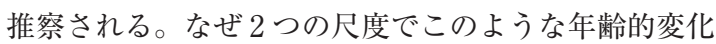
の差異が生じたのかというと, 自己効力感の定義が,
「可能性の認知」であることによると考察し得る。つま り, 特定の状況において上手く行動できるかどうか, という可能性の意味は年齢が変わっても変化しないと いうことである。その一方で, 自尊感情の場合, 年齢 によって自己への（評価的）態度の意味（尺度項目の解釈） が変化しているのではないだろうか。

Figure 2 のモデルを検討した結果，モデル 4 が支持 されたため，方法因子のみを想定すること（モデル 6) はできない。また, RSES と特性的自己効力感を同一 因子の尺度項目としてみなすこと（モデル 7) もできな い。仮に, 自尊感情と特性的自己効力感に高次因子を 想定できたとしても, 両因子の存在は結果的に認めら れる。これは, 方法因子についても言えることであり, モデル 5 を支持していない限りにおいて, RSES と特 性的自己効力感尺度における方法因子を同じ方法因子 としてみなして良いということでもない (e.g., RSESの肯 定的方法因子と特性的自己効力感尺度の肯定的方法因子は同一の 因子ではない)。しかし, 研究IIに扔いて基準変数として 取り上げたストレス得点とナルシシズム得点と方法因 子との相関のパターンは, RSES と特性的自己効力感 尺度の方法因子でそれぞれ類似していた。したがって， 研究 II の結果では, 因子構造の適合度はモデル 4 を最 善としている一方で, 方法因子の心理学的意味はモデ ル 5 のように 2 つ尺度で同じである可能性も否定は できない。因子構造の年齢間比較という観点からは, モデル 4 における因子間相関 (Table 3) では, 自尊感情 
と特性的自己効力感の相関は年齢が高くなるについて 強くなる傾向にあった。したがって，年齢が高くなる につれて, 自尊感情と特性的自己効力感の概念の共通 性は高くなる傾向にあると思われ，どちらも自己評価 であるという意味においてまとまっていく傾向にある と思われる。また，両尺度の否定的方法因子間（NSEと SEf Nega）は年齢が高くなるにつれて相関が弱くなる傾 向が示された。これは，年齢が高くなるほど，方法因 子としての意味が弱くなっていく傾向があるものと考 えられる。

さらに, 研究 II では肯定的方法因子の合成得点と否 定的方法因子の合成得点が基準変数とそれぞれ異なる 関連にあることが明らかになった。肯定的方法因子は ナルシシズム得点との正の相関によって特徴づけられ ると考えられ，小塩（1997）の結果を支持するもので あった。研究 II ではこの傾向が特に若者における特徴 であることを明らかにしている。一方, 否定的方法因 子はストレス得点との負の相関によって特徴づけられ る。こうした肯定的方法因子と否定的方法因子の特徴 は，ストレスとナルシシズムが無相関または小さい相 関であったことからも妥当なものと考えられる。さら に, 従来のように尺度を単因子としてみなして算出し た合成変数よりも，これらの方法因子の合成得点の方 が基準変数と関連性が高かった点は特筆すべき点であ る。なぜならば, 従来の自尊感情得点よりも 2 因子に 分けた場合の方が, その他の概念と強い関連を示して おり，自尊感情という概念の解釈をより適切に行える 可能性があるからである。

\section{総合考察}

本研究の目的は RSES と特性的自己効力感尺度にお ける因子構造の検討を通じて, 自己評価的尺度一般に おける肯定的方法因子と否定的方法因子の心理学的意 味を検討することであった。

本研究の結果から, RSES 並びに特性的自己効力感 尺度のそれぞれにおいて, 肯定・否定表現による方法 因子が存在することが示され, 肯定的方法因子はナル シシズムによって, 否定的方法因子はストレス反応に よって特徴づけられることが示唆された。ただし, こ の解釈は本研究が基準変数としてこの 2 変数を選択し たためによるものであって，これらの結果は方法因子 に関する一知見として限定的に説明される必要がある。

方法因子は自己評価的尺度一般に存在する可能性が あると考えられるが, 一方で, 尺度間で共通の方法因 子を持っているかどうかという点については疑問が残
る。本研究における基準変数との相関のパターンは, RSES と特性的自己効力感尺度の間で類似しており, 自 己評価的尺度一般に共通の方法因子を仮定できる可能 性も十分考えられる結果であった。しかし, 研究 II で 支持されたモデルは自尊感情と特性的自己効力感のそ れぞれに特有の方法因子が存在するモデルであったこ とからも, 自己評価的尺度一般に全く同質の方法因子 が存在するという結論にはならないと考える。この点 については今後さらなる検討が必要になる。

本研究では，因子構造に関する年齢群別の検討も 行った。その結果, 第一に, 両特性間（自尊感情と特性 的自己効力感) 並びに方法因子の合成得点間の相関が年 齢とともにそれぞれ高くなる傾向があることがわかっ た。また, 年齢が低いグループで肯定的方法因子の合 成得点とナルシシズムは強く関連した。さらに, RSES では年齢が高くなるほど SEの負荷量が大きくなり, 方 法因子の負荷量が小さくなる傾向にあったことから, RSES における肯定的・否定的方法因子が年齢を重ね ていくことで統合されていく過程が存在するかもしれ ない。これは肯定的方法因子と否定的方法因子の相関 が単純に高くなるということではなく, 概念全体とし て統合されているという意味において，特性的自己効 力感尺度以上に, RSES に興味深い発達的変化を推察 し得ると考える。

自己効力感尺度以上に RSES の発達的変化が興味深 い理由として, 研究 I の RSES の検討では項目 6 と 7 の PSE における因子負荷量が, 年齢の高い群において 負の值を示したこと（因子負荷量に正の值と負の值が混合し たこと）も挙げられる。本研究ではその原因を追究する ことはできないが, 項目の解釈が年齢によって異なる 可能性を示しているものと考えられる。仮に, RSESの 項目の解釈に発達的変化が見られるのであれば, 自尊 感情得点について若年層と高齢層を比較することにも 疑義が生じることにもなりかねないだろう。この点に ついても今後の研究課題である。

ここで, 以上の年齢的変化に関する議論について追 加分析を行った結果を示す。その分析とは, 年歯令 ループによってモデル図が異なると仮定して分析し直 すものである。仮に, 先述したような加歯による統合 過程が, 年齢別のモデル図の変化を生んでいるのであ れば, 研究 I における RSES 単独の因子構造はグルー プ 4 において単因子構造になる可能性がある。しかし, グループ 4 のみについて単因子構造を仮定した場合の 適合度は十分なあてはまりを示すものではなかった $\left(\chi^{2}=711.047, d f=27, p<.001, \mathrm{CFI}=.782, \mathrm{GFI}=.783, \mathrm{RMSEA}=\right.$ 
.192, AIC=747.047)。また, 研究 II のモデル 7 について も，グループ 4 において十分なあてはまりを示してい なかった $\left(\chi^{2}=2396.784, d f=431, p<.001, \mathrm{CFI}=.807, \mathrm{GFI}=\right.$ $.782, \mathrm{RMSEA}=.081, \mathrm{AIC}=2590.784)$ 。以上の結果を踏まえ て, 本研究の年齢的変化という意味についてより適切 に結論するならば，モデル図が変化するような年齢的 変化が起きているわけではなく，因子負荷量や因子間 相関，そして因子と基準変数との関連について年龄的 に変化している可能性がある, とするのが妥当である と考えられる。

なお, 福留他 (2017) は RSES が 2 因子構造であるこ とを報告しているが, 本研究ではモデル 3 , つまり自 尊感情と肯定的・否定的方法因子を認めるという結論 が導かれている。両者は異なる結論であるように考え られるかもしれないが, 今後, 検討されるべき課題の 内容が変更されるのではなく, どちらの研究も PSE と NSE に関するさらなる検討が必要であることを主張し ている。本論文の意義は, 特に若年層における RSES の方法因子の重要性を強調し, 方法因子の年踰的変化 と自己評価的尺度一般に関する議論へ発展させたとこ ろにある。

\section{引用文献}

安藤清志 (1987). さまざまな測定尺度 末永俊郎（編） 社会心理学研究入門 (pp. 211-228) 東京大学出版 会

Arbuckle, J. L. (2015). Amos 24.0 [Computer Program]. Chicago, IL: IBM SPSS.

Blascovich, J., \& Tomaka J. (1991). Measures of selfesteem. In J. P. Robinson \& P. R. Shaver (Eds.), Measures of personality and social psychological attitudes (pp. 115-160). San Diego, CA: Academic Press.

Boduszek, D., Hyland, P., Dhingra, K., \& Mallett, J. (2013). The factor structure and composite reliability of the Rosenberg Self-Esteem Scale among ex-prisoners. Personality and Individual Differences, 55, 877881. doi:10.1016/j.paid.2013.07.014

Brown, T. A. (2015). Confirmatory factor analysis for applied research (2nd ed.). New York: Guilford Press.

Buss, A. H. (1986). Social behavior and personality. Hillsdale, NJ: Lawrence Erlbaum Associates. (バス, A. H. 大㴊憲一（監訳）（1991）. 対人行動とパーソナ リティ 北大路書房)
Campbell, D. T., \& Fiske, D. W. (1959). Convergent and discriminant validation by the multitrait-multimethod matrix. Psychological Bulletin, 56, 81-105.

Carmines, E. G., \& Zeller, R. A. (1979). Reliability and validity assessment. Beverly Hills, CA: Sage.

Cheek, J. M., \& Buss, A. H. (1981). Shyness and sociability. Journal of Personality and Social Psychology, 41, 330-339.

DiStefano, C., \& Motl, R. W. (2006). Further investigating method effects associated with negatively worded items on self-report surveys. Structural Equation Modeling, 13, 440-464. doi:10.1207/s15328007sem 1303_6

Eid, M. (2000). A multitrait-multimethod model with minimal assumptions. Psychometrika, 65, 241-261. doi:10.1007/BF02294377

藤田尚文・福留広大 - 古口高志 - 小林 渚 (2017). ス トレスの空モデル—防御因子が制御する空によるス トレス反応の加算 教育心理学研究, 65, 12-25. doi: 10.5926/jjep.65.12

福留広大 · 藤田尚文 · 戸谷彰宏 - 小林 渚 ·古川善也 森永康子 (2017). 中学生におけるローゼンバーグ自 尊感情尺度の 2 側面一「肯定的自己像の受容」と 「否定的自己像の拒否」教育心理学研究, 65, 183196. doi:10.5926/jjep.65.183

Gana, K., Saada, Y., Bailly, N., Joulain, M., Hervé, C., \& Alaphilippe, D. (2013) . Longitudinal factorial invariance of the Rosenberg Self-Esteem Scale: Determining the nature of method effects due to item wording. Journal of Research in Personality, 47, 406-416. doi:10.1016/j.jrp.2013.03.011

Hart, E. A., Leary, M. R., \& Rejeski, W. J. (1989). The measurement of social physique anxiety. Journal of Sport and Exercise Psychology, 11, 94-104.

今津芳恵 - 村上正人 - 小林 恵 - 松野俊夫 - 椎原康史 · 石原慶子…览玉昌久 (2006). Public Health Research Foundation ストレスチェックリスト・ショート フォームの作成一信頼性・妥当性の検討 心身医学, 46, 301-308.

Judge, T. A., Erez, A., Bono, J. E., \& Thoresen, C. J. (2002). Are measures of self-esteem, neuroticism, locus of control, and generalized self-efficacy indicators of a common core construct? Journal of Personality and Social Psychology, 83, 693-710. doi: 10.1037/0022-3514.83.3.693 
株式会社社会情報サービス（2016）。 BellCurve for Excel 2.13 [Computer Program]. Tokyo: Social Survey Research Information Co., Ltd.

Kenny, D. A. (1976). An empirical application of confirmatory factor analysis to the multitrait-multimethod matrix. Journal of Experimental Social Psychology, $12,247-252$.

Lance, C. E., Noble, C. L., \& Scullen, S. E. (2002). A critique of the correlated trait-correlated method and correlated uniqueness models for multitrait-multimethod data. Psychological Methods, 7, 228-244. doi: 10.1037//1082-989X.7.2.228

Lindwall, M., Barkoukis, V., Grano, C., Lucidi, F., Raudsepp, L., Liukkonen, J., \& Thøgersen-Ntoumani, C. (2012). Method effects: The problem with negatively versus positively keyed items. Journal of Personality Assessment, 94, 196-204. doi:10.1080/00223891.2011.6 45936

Marsh, H. W., \& Bailey, M. (1991). Confirmatory factor analyses of multitrait-multimethod data: A comparison of alternative models. Applied Psychological Measurement, 15, 47-70. doi:10.1177/014662169101500106

Marsh, H. W., \& Grayson, D. (1995). Latent variable models of multitrait-multimethod data. In R. H. Hoyle (Ed.), Structural equation modeling: Concepts, issues, and applications (pp. 177-198). Thousand Oaks, CA: Sage.

Marsh, H. W., Scalas, L. F., \& Nagengast, B. (2010). Longitudinal tests of competing factor structures for the Rosenberg Self-Esteem Scale: Traits, ephemeral artifacts, and stable response styles. Psychological Assessment, 22, 366-381. doi:10.1037/a0019225

Mullen, S. P., Gothe, N. P., \& McAuley, E. (2013). Evaluation of the Rosenberg Self-Esteem Scale in older adults. Personality and Individual Differences, 54, 153-157. doi:10.1016/j.paid.2012.08.009

成田健一 一下仲順子 - 中里克治 - 河合千恵子 - 佐藤眞 一・長田由紀子（1995). 特性的自己効力感尺度の検 討一生涯発達的利用の可能性を探る 教育心理学研 究, 43, 306-314. doi:10.5926/jjep1953.43.3_306

小塩真司 (1997). 自己愛傾向に関する基礎的研究一自 尊感情, 社会的望ましさとの関連 名古屋大學教育 學部紀要 心理学, 44, 155-163.
小塩真司 · 岡田 涼 - 茂垣まどか・並川努 ·脇田貴文 (2014). 自尊感情平均值に及ぼす年龄と調査年の影 響一Rosenberg の自尊感情尺度日本語版のメ夕分析 教育心理学研究, 62, 273-282. doi:10.5926/jjep.62.273

Rosenberg, M. (1965). Society and the adolescent selfimage. Princeton, NJ: Princeton University Press.

Schmitt, D. P., \& Allik, J. (2005). Simultaneous administration of the Rosenberg Self-Esteem Scale in 53 nations: Exploring the universal and culture-specific features of global self-esteem. Journal of Personality and Social Psychology, 89, 623-642. doi:10.1037/00223514.89.4.623

清水和秋 · 吉田昂平 (2008). Rosenberg 自尊感情尺度 のモデル化一wording と項目配置の影響の検討 関 西大学社会学部紀要, 39, 69-97.

清水裕 (2001). 自己評価 - 自尊感情 山本真理子 (編) 堀洋道 (監修) 心理測定尺度集 1 一人間の 内面を探る 自己・個人内過程 (pp. 29-31) サイエ ンス社

田村紋女 · 小塩真司 - 田中圭介 - 増井啓太 - Jonason, P. K. (2015). 日本語版 Dark Triad Dirty Dozen (DTDD-J) 作成の試み パーソナリティ研究, 24, 26-37. doi:10.2132/personality.24.26

田中道弘 (2006). Rosenberg の自尊心尺度の再検討 埼玉学園大学紀要 人間学部篇, 6, 135-139.

Urbán, R., Szigeti, R., Kökönyei, D., \& Demetrovics, Z. (2014). Global self-esteem and method effects: Competing factor structures, longitudinal invariance, and response styles in adolescents. Behavior Research Methods, 46, 488-498. doi:10.3758/s13428-013-0391-5 山本真理子・松井 豊 - 山成由紀子 (1982). 認知され た自己の諸側面の構造 教育心理学研究, 30, 64-68. doi:10.5926/jjep1953.30.1_64

付 記

1）本研究はJSPS 科研費（研究課題 JP16J03013）に よる補助により実現しました。ここに記して謝意を表 します。

2) ご助言を賜りました藤田尚文先生（元高知大学教 授）に深く感謝申し上げます。また，查読者の先生方， 調査にご協力頂いた皆様に心より御礼申し上げます。 (2017.8.27 受稿, 2018.5.29 受理) 


\section{Age-Related Differences in the Positive and Negative Method Factors on Self-Evaluation Scales: The Rosenberg Self-Esteem Scale and the Self-Efficacy Scale}

KOUDAI FUKUDOME (HIROSHIMA UNIVERSITY; JAPAN SOCIETY FOR THE PROMOTION OF SCIENCE) AND YASUKO MORINAGA (HIROSHIMA UNIVERSITY)

JAPANESE JOURNAL OF EDUCATIONAL PSYCHOLOGY, 2018, 66, 212-224

The results of exploratory factor analyses of some self-evaluation scales often reveal that such scales have 2 method factors: positive (non-reversed wording) and negative (reversed wording). The present study used the Rosenberg Self-Esteem Scale and the Self-Efficacy Scale to examine whether these 2 factors exist generally in any self-evaluation scale, and, if so, how they are related to age differences. The participants were Japanese people $(N=$ 2,830; age range, 15 to 69 years). Study 1 examined a hypothesized model consisting of 1 trait factor of self-esteem and the positive and negative method factors. The prediction of a higher correlation between the positive and negative factors as age increased was supported by the results. Study 2 analyzed the Rosenberg Self-Esteem Scale and the Self-Efficacy Scale simultaneously. The results supported the model, which included 2 trait constructs and 4 method factors, with 1 trait construct and 2 method factors for each of the 2 scales. However, a series of correlational analyses suggested that there may be common method factors in the 2 self-evaluation scales, because the pattern of correlations between narcissism and the positive method factor on the Rosenberg Self-Esteem Scale was similar to the pattern of correlations between narcissism and the positive method factor on the Self-Efficacy Scale.

Additionally, the pattern of correlations between participants' psychological stress responses and the negative method factor on the Rosenberg Self-Esteem Scale was similar to the pattern on the Self-Efficacy Scale. Moreover, these results suggest that changes due to age in the factor loadings of the Rosenberg Self-Esteem Scale and the Self-Efficacy Scale might be different.

Key Words: Rosenberg Self-Esteem Scale, Self-Efficacy Scale, confirmatory factor analysis, narcissism, psychological stress response 